\title{
The Effect of Quality Perception, Perception Risk, and Perception of Price Interest in Buying DFSK Glory 580
}

\author{
Daiwan $^{1}$, Dr. M. Mukti Ali, ST., MM² \\ Mercu Buana University, Jakarta
}

\begin{abstract}
This study aims to determine and explain the effect of perceived quality, perceived risk, and perceived price on the buying interest of DFSK Glory $\mathbf{5 8 0}$. Respondents in this study were 150 people, data collection was carried out through questionnaires, data were analyzed using Multiple Linear Regression analysis ( using SPSS 25.0 tools). The results showed that: (1) There was an effect of Perception of Quality (X1) on Consumer Purchase Interest (Y) partially. (2) There is a partial influence of Risk Perception (X2) on Consumer Purchase Interest (Y). (3) There is a partial influence of Price Perception (X3) on Consumer Purchase Interest (Y). (4) There is an influence from Quality Perception (X1), Risk Perception (X2),
\end{abstract}

Based on the analysis of the correlation matrix between dimensions, the performance dimension in the Quality Perception variable is indispensable for each increase in Consumer Purchase Interest (Y) especially in the Interest dimension. The Dimension of Function in the Risk Perception variable is indispensable for any increase in Consumer Purchase Interest (Y) especially in the Interest dimension. The Quality Dimension in the Price Perception variable is indispensable for any increase in Consumer Purchase Interest (Y) especially in the Action dimension.

Keywords:- Quality Perception, Risk Perception, Price Perception, Buying Interest

\section{INTRODUCTION}

Chongqing Sokon Industry Group Stock CO., LTD. is a manufacturing entity with the core business of machinery and new energy vehicles and the main business of automobiles. Now a complete industrial chain that includes independent R\&D, manufacturing, sales and services of cars, machinery, parts has been formed. The company's business also involves vehicle rental and Internet consumer financing. There are several subsidiaries and DFSK Motor CO., LTD, a joint venture between Sokon Group and Dongfeng Motor (one of the global Fortune 500 companies). DFSK's main products include conventional SUVs and MPVs, and pure electric vehicles and energyefficient and environmentally friendly engines. PT. Sokonindo Automobile is a joint venture company between Sokon Group (Hongkong) Company Limited and PT. Emperor Motorindo Industri from Indonesia. The Sokonindo factory is located in the Cikande Modern Industrial Estate, Serang - Banten, with an area of 20 hectares. PT. Sokonindo Automobile ensures to provide customers with reliable and reliable products and services, protecting them throughout the journey and eliminating all worries. DFSK has evolved into a Global Company with world-recognized standards. Now present in Indonesia with the latest products and technologies that are believed to be able to compete in the intense competition of the automotive market in Indonesia.

\section{LITERATURE REVIEW}

\section{> Quality Perception}

Quality perception is the consumer's perception of the overall quality or excellence of a product related to what is expected by consumers. Because the perception of quality cannot be determined objectively. Consumer perception will involve what is important for consumers, because each consumer has different interests in a product. The object perceived is product quality whose measurement is based on the dimensions of product quality by referring to the opinion of Garvin (Durianto et al, 2011) which says that there are seven characteristic dimensions used by consumers in perceiving product quality. The seven dimensions of product quality characteristics are: (1) Performance, involving a variety of key operational characteristics, for example the operational characteristics of a car are speed, acceleration, steering system and comfort (2) Service, reflects the ability to provide services to the product. For example, certain brand cars provide damage service shops or warranty services (3) Durability, reflect the economic life of the product, or some product can be used. For example certain brand cars that position themselves as durable cars even though they are over 5 years old but still function properly (4) Reliability, consistency of the performance produced by a product from one purchase to the next (5) Characteristics of products, parts additional from the product. These additional sections emphasize that the company understands the needs of its dynamic violations in accordance with developments, namely regarding the style, taste, appearance, product odor and attractiveness (6) Conformity with specifications, is a view of the quality of the manufacturing process (no product defects) in accordance with predetermined and tested specifications (7) Results, leading to perceived quality involving the previous six dimensions. If the company cannot produce a good final product, it is likely that the product will not have other important quality attributes. Martinich (2017) in Kotler and Keller (2012) suggested that there are six dimensions of characteristics used by consumers in perceiving the quality of a product. 


\section{$>$ Risk Perception}

Risk perception according to Kotler (2012), is defined as unintended consequences and consumers want to avoid these risks, which arise due to the purchase of a product. Meanwhile Schiffman and Kanuk (2013) define perceived risk as the uncertainty faced by consumers when they cannot predict the impact of their purchasing decisions. Two important things that understand this risk perception are the existence of uncertainty and consequences. For consumers, these consequences are the benefits or outcomes that will be felt after buying or consuming a product. Referring to the opinion of Sumarwan (2015), interpreting perceived risk as a belief that potential products have negative consequences. Risk perception will arise in consumers' minds if the purchase decision involves extensive information search. According to Mowen and Minor (2012: 32) risk perception can be divided into six types, as follows: (1) Functional risk (functional risk or performance risk) that is risk because the product does not function as expected (2) Financial risk (financial risk ) or (monetary risk), the financial difficulties faced by a consumer after he buys a product and service (3) physical risk, which is the negative impact that will be felt by consumers because of using a product (4) psychological risk (physical risk), namely feeling, emotions, or egos that consumers will feel from consuming, buy or use a product (5) Social risk (social risk) is the consumer's perception of opinions about himself from people around him (social acceptance) because buying or consuming a product or service (6) Time risk is time vain that will be spent by consumers consuming or buying a product or service. The risk of opportunity loss is the loss of opportunity or doing other things because consumers use, buy or consume a product and service.

\section{$>$ Price Perception}

According to Hawkins, Nothesbaugh \& Best in Leonardo and Erwan (2012: p45), perception is a process that begins with consumer exposure and attention to marketing stimuli and ends with consumer interpretation. According to Freddy Rangkuti (2012: 47) in the perception of price is measured based on customer perception that is by asking customers what variables they think are most important in choosing a product. Price perception (Nagle \& Hogan, 2016) is formed by 4 main dimensions, namely: (1) Quality perception, consumers tend to prefer products that are expensive when the information obtained is only the price of the product. Consumer perceptions of product quality are influenced by their perceptions of names, brands, store names, the warranty provided and the country that produced the product. (2) Perception of costs incurred, in general consumers assume that the price is the costs incurred to get a product. But consumers have different perceptions of the costs incurred even for the same product. This depends on the situation and conditions experienced by consumers. (3) Perception of price differences, evaluations of consumers of the price difference offered to the basic price that is known by consumers. (4) Reference prices, prices formed by customers based on two things, among others: prices according to the customer's experience (internal reference price) and prices that are informed by others or advertisements on the outside seen by customers (external reference prices) . (2) Perception of costs incurred, in general consumers assume that the price is the cost incurred to get a product. But consumers have different perceptions of the costs incurred even for the same product. This depends on the situation and conditions experienced by consumers. (3) Perception of price differences, evaluations of consumers of the price difference offered to the basic price that is known by consumers. (4) Reference prices, prices formed by customers based on two things, among others: prices according to the customer's experience (internal reference price) and prices that are informed by others or advertisements on the outside seen by customers (external reference prices) . (2) Perception of costs incurred, in general consumers assume that the price is the cost incurred to get a product. But consumers have different perceptions of the costs incurred even for the same product. This depends on the situation and conditions experienced by consumers. (3) Perception of price differences, evaluations of consumers of the price difference offered to the basic price that is known by consumers. (4) Reference prices, prices formed by customers based on two things, among others: prices according to the customer's experience (internal reference price) and prices that are informed by others or advertisements on the outside seen by customers (external reference prices) . in general consumers assume that the price is the cost incurred to get a product. But consumers have different perceptions of the costs incurred even for the same product. This depends on the situation and conditions experienced by consumers. (3) Perception of price differences, evaluations of consumers of the price difference offered to the basic price that is known by consumers. (4) Reference prices, prices formed by customers based on two things, among others: prices according to the customer's experience (internal reference price) and prices that are informed by others or advertisements on the outside seen by customers (external reference prices) . in general consumers assume that the price is the cost incurred to get a product. But consumers have different perceptions of the costs incurred even for the same product. This depends on the situation and conditions experienced by consumers. (3) Perception of price differences, evaluations of consumers of the price difference offered to the basic price that is known by consumers. (4) Reference prices, prices formed by customers based on two things, among others: prices according to the customer's experience (internal reference price) and prices that are informed by others or advertisements on the outside seen by customers (external reference prices) . But consumers have different perceptions of the costs incurred even for the same product. This depends on the situation and conditions experienced by consumers. (3) Perception of price differences, evaluations of consumers of the price difference offered to the basic price that is known by consumers. (4) Reference prices, prices formed by customers based on two things, among others: prices according to the customer's experience (internal reference price) and prices informed by others or advertisements on the outside seen by customers (external reference prices) . But consumers have different 
perceptions of the costs incurred even for the same product. This depends on the situation and conditions experienced by consumers. (3) Perception of price differences, evaluations of consumers of the price difference offered to the basic price that is known by consumers. (4) Reference prices, prices formed by customers based on two things, among others: prices according to the customer's experience (internal reference price) and prices informed by others or advertisements on the outside seen by customers (external reference prices).

\section{$>$ Purchase Interest}

According to Kotler and Keller (2012) states that buying interest is a customer's behavior that arises in response to objects that indicate the customer's desire to make a purchase. According to Kotler and Keller (2012: 503) explained that indicators of buying interest are through the AIDA stimuli model, namely attention, interest, desire, and action. Explanation of each indicator of buying interest is as follows: (1) Attention, one's buying interest begins with the stage of attention to a product, after hearing or seeing a product promoted by the company. (2) Interests, after getting information about the products promoted by the company, consumer interest arises in the product. If consumers are impressed with the stimuli provided by the company, then at this stage there will be a sense of interest in the products offered. (3) Desire, after consumers explore the advantages of the product, then at this stage consumers will have the desire and desire to buy the product. (4) Actions, at this stage, consumers have passed several stages, starting from seeing and hearing a product being promoted, so that attention, interest and interest in the product arise. If there is a strong desire and desire, it will take the decision to buy the product. consumers have gone through several stages, namely starting from seeing and hearing a product being promoted, so that attention, interest and interest in the product arise. If there is a strong desire and desire, it will take the decision to buy the product. consumers have gone through several stages, namely starting from seeing and hearing a product being promoted, so that attention, interest and interest in the product arise. If there is a strong desire and desire, it will take the decision to buy the product.

\section{THEORETICAL FRAMEWORK}

The framework is a combination of theoretical arguments and is supported by empirical evidence or the results of previous research on the proposed research problem. The framework of thought is arranged based on the relationship between variables according to the theory used as a reference.

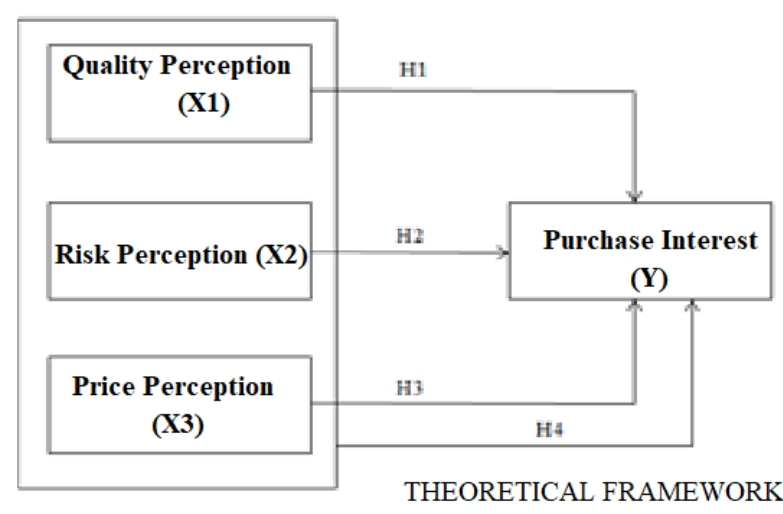

Fig 1

H1 : Allegedly the perception of quality has a positive and significant effect on buying interest in Glory 580 .

$\mathrm{H} 2$ : It is suspected that risk perception has a positive and significant effect on buying interest in Glory 580 .

H3 : It is suspected that price perception has a positive and significant effect on buying interest in Glory 580.

H4 : Allegedly the perception of quality, risk perception, and price perception together have a positive and significant effect on Glory 580 buying interest.

\section{SAMPLES AND POPULATIONS}

The population for this study is all people who have an interest in buying a new car. The population in this study is unknown in number. Because the population is large, and this study is not possible to study everything in the population, such as limited funds, manpower and time, the study can use samples drawn from that population (Sugiyono, 2011). Sampling is done by insindental technique, namely determination of samples based on coincidence, ie anyone who incidentally / insindental meets with the researcher can be used as a sample, if it is deemed that the person met by chance is suitable as a source of data. In this study the number of samples used was 150 respondents with reasons to facilitate data processing and for better testing results.

\section{METHOD OF COLLECTING DATA}

To obtain primary data the data collection methods used in this study were through questionnaires. In this study, the authors conducted a data collection method by distributing questionnaires online using Google forms and directly surveying.

\section{DATA ANALYSIS METHOD}

The method of data analysis in this study uses Multiple Linear Regression analysis with SPSS 25.0 software support. 


\section{RESULTS AND DISCUSSION}

\section{A. Descriptive Analysis of Respondents}

Characteristics of 150 respondents who are Prospective Consumers who have an interest in buying a new car are as follows: (a) Characteristics of the majority of DFSK Glory 580 respondents are 117 men or $78 \%$ and women are 33 people. This shows that men really go to showrooms more often, or to automotive exhibition venues whether they shop or just look at the latest car products and men understand more about machines than women. (b) Characteristics of the majority of DFSK Glory 580 respondents aged 20-30 years are 105 respondents (70\%). This is because including the age of 20-30 is a mature age and has an income so that it can make purchases. (c) The majority of respondents work as private employees totaling 121 respondents $(80.67 \%)$. This is because a private worker then the respondent already has an income. So it is possible to buy a car. In addition, because of his work as an employee, using a vehicle can facilitate mobility and provide security for employees. (d) Characteristics of respondents based on income, 118 respondents (78\%) have income between Rp. 3-7 million. This can happen because in terms of price, the DFSK Glory 580 is quite cheap among SUVs with other brands in the respondent's homeland in monthly income is enough to pay monthly car installments. In addition, because of his work as an employee, using a vehicle can facilitate mobility and provide security for employees. (d) Characteristics of respondents based on income, 118 respondents $(78 \%)$ have income between Rp. 3-7 million. This can happen because in terms of price, the DFSK Glory 580 is quite cheap among SUVs with other brands in the respondent's homeland in monthly income is enough to pay monthly car installments. In addition, because of his work as an employee, using a vehicle can facilitate mobility and provide security for employees. (d) Characteristics of respondents based on income, 118 respondents (78\%) have income between Rp. 3-7 million. This can happen because in terms of price, the DFSK Glory 580 is quite cheap among SUVs with other brands in the respondent's homeland in monthly income is enough to pay monthly car installments.

\section{B. Variable Descriptive Analysis}

Indicators on the results of the distribution of quality variables obtained an average value with a low category where the highest value of 3.35 contained in the statement "I think the Glory 580 car has a good safety standard". From this statement shows that the DFSK Glory 580 is equipped with various smart features and the best safety features in its class, such as anti-lock brake system (ABS), electronic brake force distribution (EBD), electronic brake assist (EBA), electronic parking brake (EPB) ), HHC uphill assist function, tire pressure monitoring system (TPMS), driving recorder, parking camera, 10-inch touch screen, leather-coated steering wheel with multi-function keys and smart key. For indicators on the results of the distribution of risk perception variables obtained an average value with a low category where the highest value is 3.43 contained in the statement "I think the Glory 580 car will be useful for me". This statement shows that risk perception on the dimensions of financial risk as well as indicators of the lack of suitability of benefits have an influence on buying interest. For indicators on the results of the distribution of price perception variables obtained an average value with a low category where the highest value of 3.33 contained in the statement "In my opinion the Glory 580 price is proportional to the quality of the product". From this statement shows that this explains that the quality of the Glory 580 car is in accordance with the price paid by consumers so that consumers are not disappointed because the price offered is in accordance with the quality of the Glory 580 car. In terms of value for money, the price comparison with other brands of SUV is quite far adrift. While all indicators on the results of the distribution of buying interest variables obtained an average value with a fairly high category where the highest value of 3.56 contained in the statement "I will take the decision to buy Glory 580". From this statement, it shows that from the evaluation results for the answers to the statements of the variable perception of quality, risk perception and price perception, ultimately prospective consumers feel they have a tendency to make a purchase of a brand or take actions related to the purchase and are measured by the level of the likelihood of consumers making a purchase, namely DFSK Glory 580. 56 contained in the statement "I will make the decision to buy Glory 580". From this statement, it shows that from the evaluation results for the answers to the statements of the variable perception of quality, risk perception and price perception, ultimately prospective consumers feel they have a tendency to make a purchase of a brand or take actions related to the purchase and are measured by the level of the likelihood of consumers making a purchase, namely DFSK Glory 580.56 contained in the statement "I will make the decision to buy Glory 580". From this statement, it shows that from the evaluation results for the answers to the statements of the variable perception of quality, risk perception and price perception, ultimately prospective consumers feel a tendency to make a purchase of a brand or take actions related to the purchase and measured by the level of the likelihood of consumers making a purchase, namely DFSK Glory 580.

\section{Validity test}

The results of the validity test in this study found all items of the statement obtained $r$ count greater than $r$-table. This shows that all statement items on each variable are valid so that the statement can be used as a research instrument $(\mathrm{df}=\mathrm{n}-2$ obtained $\mathrm{r}$ table 0.16$)$.

\section{Reliability Test}

The test is carried out by comparing the Cronbach Alpha numbers where the minimum Cronbach Alpha value is 0.6 or $\geq 0.6$. 


\begin{tabular}{lccc}
\hline Variabel & $\begin{array}{c}\text { Nilai } \\
\text { Cronbach's } \\
\text { Alphia }\end{array}$ & Syarat & Keterangan \\
\hline Persepsi Kualitas & 0.765 & $>0.6$ & Reliabel \\
Persepsi Resiko & 0.766 & $>0.6$ & Reliabel \\
Persepsi Harga & 0.774 & $>0.6$ & Reliabel \\
Minat Beli Konsumen & 0.701 & $>0.6$ & Reliabel \\
\hline
\end{tabular}

Table 1:- Variable Indicator Reliability Test Results

Based on table 1 thus the variable Quality Perception (X1), Risk Perception (X2), Price Perception (X3), and Consumer Purchase Interest variable (Y), are declared reliable.

\section{E. Normality test}

\begin{tabular}{llcccc}
\hline \multicolumn{5}{c}{ One-Sample Kolmogorov-Smirnov Test } \\
\hline & & Persepsi & Persepsi & Persepsi & Minat \\
& Kualitas & Resiko & Harga & Beli \\
\hline $\mathrm{N}$ & 150 & 150 & 150 & 150 \\
Normal Parameters ${ }^{\mathrm{a}, \mathrm{b}}$ & Mean & 3.091 & 3.180 & 3.020 & 3.454 \\
& Std. & 0.590 & 0.536 & 0.585 & 0.302 \\
& Deviation & & & & \\
Test Statistic & & $\mathbf{0 . 0 7 2}$ & $\mathbf{0 . 0 6 9}$ & $\mathbf{0 . 0 7 2}$ & $\mathbf{0 . 0 4 3}$ \\
Asymp. Sig. (2-tailed) & & $\mathbf{. 0 5 5}^{\mathrm{c}}$ & $\mathbf{. 0 8 1 ^ { \mathrm { c } }}$ & $\mathbf{. 0 5 5}^{\mathrm{c}}$ & $\mathbf{. 2 0 0 ^ { \mathrm { c } } \text { d }}$ \\
\hline
\end{tabular}

a. Test distribution is Normal

b. Calculated from data.

c. Lilliefors Significance Correction.

d. This is a lower bound of the true significance.

Table 2:- Data Normality Test Results

Kolmogorov-Smirnov normality test results, the results obtained Sig. of the four variables above more than the value of $\alpha=0.05$, and the calculated KS value $<\mathrm{KS}$ value of the table $(1.35 / \sqrt{ } 150=0.11)$. Thus the Kolomogorov-Smirnov test results of the four variables above have met the normality requirements with the Sig. > $\alpha=0.05$. It can be concluded that the data tested has a normal data distribution.

\section{F. Multicollinearity Test}

One of the multicollinearity tests commonly used is the Variance Inflation Factor (VIF) test, if the VIF value for the $\mathrm{X}$ variable $<10$ then multicollinearity does not occur.

\begin{tabular}{|c|c|c|}
\hline \multicolumn{3}{|c|}{ Coefficients $^{\mathrm{a}}$} \\
\hline \multirow{2}{*}{ Model } & \multicolumn{2}{|c|}{ Collinearity Statistics } \\
\hline & Tolerance & VIF \\
\hline \multicolumn{3}{|l|}{ (Constant) } \\
\hline Persepsi Kualitas & 0.820 & 1.220 \\
\hline Persepsi Resiko & 0.888 & 1.126 \\
\hline Persepsi Harga & 0.785 & 1.274 \\
\hline
\end{tabular}

Table 3:- Multicollinearity Test Results
The VIF value of each variable is less than 10 . This can be concluded that the tested data does not occur multicollinearity.

\section{G. The coefficient of determination $\left(R^{2}\right)$}

The coefficient of determination (R2) essentially measures how far the model's ability to explain variations in the dependent variable.

\begin{tabular}{cccccc}
\hline \multicolumn{5}{c}{ Model Summary $^{\mathrm{b}}$} \\
\hline \multirow{2}{*}{ Model } & $\mathrm{R}$ & $\mathrm{R}$ & Adjusted & Std. Error of the \\
& & Square & R Square & Estimate \\
\hline 1 & & $.909^{\mathrm{a}}$ & 0.826 & 0.822 & 0.127
\end{tabular}

\section{a. Predictors: (Constant), Persepsi Harga, Persepsi Resiko, Persepsi Kualitas \\ b. Dependent Variable: Minat Beli}

Table 4:- Coefficient of determination (R2)

Based on Table 4, the known value of Adjusted $\mathrm{R}$ Square $=0.822$. This shows that $82.2 \%$ of Consumer Purchase Interest ( $\mathrm{Y}$ ) is influenced by the Quality Perception variable (X1), Risk Perception variable (X2), and Price Perception variable (X3) while the rest (100\% $82.2 \%)$ is $17,8 \%$ Consumer Purchase Interest (Y) is influenced by other factors outside this study.

\section{H. Simultaneous Significance Test (Test F)}

Used to find out whether together the independent variables significantly influence the dependent variable.

\begin{tabular}{lcrrrrr}
\hline \multicolumn{6}{c}{ ANOVA $^{\mathbf{a}}$} \\
\hline \multirow{2}{*}{ Model } & $\begin{array}{c}\text { Sum of } \\
\text { Squares }\end{array}$ & df & $\begin{array}{c}\text { Mean } \\
\text { Square }\end{array}$ & F & Sig. \\
\hline 1 & Regression & 11.214 & 3 & 3.738 & 230.711 & $.000^{b}$ \\
Residual & 2.366 & 146 & 0.016 & & \\
Total & 13.580 & 149 & & & \\
\multicolumn{7}{c}{ a. Dependent Variable: Minat Beli } \\
b. Predictors: (Constant), Persepsi Harga, Persepsi Resiko, Persepsi Kualitas \\
Table 5:- Simultaneous Significance Test (Test F)
\end{tabular}

Given the value of $\mathrm{F}=230.711$, and the value of Sig. $=0,000$, while the $\mathrm{F}$ value of the table with $\mathrm{df}(3,146)=$ 2.67. Thus H0 is rejected, this is the Quality Perception variable (X1), the Risk Perception variable (X2), and the Price Perception variable (X3), together have a significant effect on the Consumer Purchase Interest (Y) variable.

\section{Multiple Linear Regression Analysis \& Hypothesis Testing}

Hypothesis testing to determine the effect of each independent variable individually on the dependent variable. To calculate the t-table used the provisions $\mathrm{df}=\mathrm{nk}$ $=150-4=146)=1.97$ at the level of significant $(\alpha)$ of $5 \%$ (error rate of $5 \%$ or 0.05 ) or $95 \%$ confidence level or 0.95 , so if the error rate of a variable is more than $5 \%$, it means that the variable is not significant. 


\begin{tabular}{|c|c|c|c|c|c|}
\hline \multicolumn{6}{|c|}{ Coefficients $^{\mathrm{a}}$} \\
\hline \multirow{3}{*}{ Model } & \multirow{2}{*}{\multicolumn{2}{|c|}{$\begin{array}{l}\text { Unstandardize } \\
\text { d Coefficients }\end{array}$}} & \multirow{3}{*}{$t$} & \multirow{3}{*}{ Sig. } & \multirow{3}{*}{ Keterangan } \\
\hline & & & & & \\
\hline & B & $\begin{array}{l}\text { Std. } \\
\text { Error }\end{array}$ & & & \\
\hline \multirow{2}{*}{$\begin{array}{ll}1 & \text { (Constant) } \\
& \text { Persepsi Kualitas }\end{array}$} & 1.491 & 0.078 & 19.008 & 0.000 & \\
\hline & 0.315 & 0.020 & 16.140 & 0.000 & $\begin{array}{l}\text { Berpengaruh } \\
\text { Signifikan Positif }\end{array}$ \\
\hline Persepsi Resiko & 0.196 & 0.021 & 9.487 & 0.000 & $\begin{array}{l}\text { Berpengaruh } \\
\text { Signifikan Positif }\end{array}$ \\
\hline Persepsi Harga & 0.121 & 0.020 & 6.011 & 0.000 & $\begin{array}{l}\text { Berpengaruh } \\
\text { Signifikan Positif }\end{array}$ \\
\hline a. Dependent Variabl & : Minat 1 & & & & \\
\hline
\end{tabular}

Sumber: Hasil analisa menggunakan SPSS 25.0

Table 6:- Hypotheses \& Multiple Linear Regression

From Table 6, it is found that: (1) There is an effect of Perception of Quality (X1) on Consumer Purchase Interest (Y) partially. Shows that the relationship between Quality Perception (X1) and Consumer Purchase Interest (Y) is significant with a $\mathrm{t}$-count of $16.140(\mathrm{t}$-count $>\mathrm{t}$ table $(\mathrm{df}=$ $146)=1.97)$ and a Sig. $=0,000$. The coefficient value is positive that is equal to 0.315 which shows that the direction of the relationship between Quality Perception (X1) with Consumer Purchase Interest is positive at $31.5 \%$. Thus the H1 hypothesis in this study which states that "Quality Perception (X1) has a significant effect on Consumer Purchase Interest (Y)" is accepted. (2) There is a partial influence of Risk Perception (X2) on Consumer Purchase Interest (Y). Shows that the relationship between Risk Perception (X2) and Consumer Purchase Interest (Y) is significant with a t-test of 9,487 ( $\mathrm{t}$-count $(\mathrm{df}=146)$ > 1.97 ) and a Sig. $=0,000$. The coefficient value is positive that is equal to 0.196 which indicates that the direction of the relationship between Risk Perception (X2) with Consumer Purchase Interest is positive at $19.6 \%$. Thus the $\mathrm{H} 2$ hypothesis in this study which states that "Risk Perception (X2) has a significant effect on Consumer Purchase Interest (Y) partially" is accepted. (3) There is a partial influence of Price Perception (X3) on Consumer Purchase Interest (Y). Show that the relationship between Price Perception (X3) and Consumer Purchase Interest (Y) is significant with a t-test of $6.011(\mathrm{t}$-count $(\mathrm{df}=146)>1.97$ and Sig value $=0.000$. The coefficient value is positive that is 0.121 which shows that the direction of the relationship between Price Perception (X3) and Consumer Purchase Interest is positive at $12.1 \%$. Thus the $\mathrm{H} 3$ hypothesis in this study which states that "Price Perception (X3) has a significant effect on Consumer Purchase Interest (Y) partially" is accepted. (4) There is an effect of Quality Perception (X1), Risk Perception (X2), and Price Perception (X3) on Consumer Purchase Interest (Y) simultaneously or together. The F value of the table with $\mathrm{df}$ (3.146) is 2.67. These results indicate that the calculated F value $(230,711)>$ from the F table (2.67), and the Sig. equal to 0,000 smaller than $\alpha=0.05$, thus $\mathrm{Ha}$ is accepted that there is a simultaneous influence on the variable Quality Perception (X1), Risk Perception (X2), and Price Perception (X3) of Consumer Purchase Interest (Y). So the hypothesis $\mathrm{H} 4$ in this study which states that "Quality Perception (X1), Risk Perception (X2), and Price Perception (X3) have a significant or simultaneous significant effect on Consumer Purchase Interest (Y)" accepted.

\section{J. Correlation Matrix Between Variables}

Correlation analysis is a statistical analysis that measures the degree of relationship involving more than one independent variable (X1, X2, X3) and one dependent variable $(\mathrm{Y})$.

\begin{tabular}{|c|c|c|c|c|c|}
\hline \multirow{4}{*}{ Variabel } & \multicolumn{5}{|c|}{ Correlations } \\
\hline & \multirow{3}{*}{ Dimensi } & \multicolumn{4}{|c|}{ Minat Beli (Y) } \\
\hline & & 4.1 & 4.2 & 4.3 & 4.4 \\
\hline & & Perhatian & Minat & Keinginan & Tindakan \\
\hline \multirow{6}{*}{$\begin{array}{l}\text { Persepsi } \\
\text { Kualitas } \\
\text { (X1) }\end{array}$} & 1.1 Performance & 0.172 & 0.684 & 0.118 & 0.294 \\
\hline & $\begin{array}{l}1.2 \text { Range and } \\
\text { Type of Features }\end{array}$ & 0.512 & 0.343 & 0.519 & 0.495 \\
\hline & $\begin{array}{l}1.3 \text { Reliability and } \\
\text { durability }\end{array}$ & 0.501 & 0.364 & 0.45 & 0.461 \\
\hline & $\begin{array}{l}\text { 1.4 Maintability } \\
\text { and Serviceability }\end{array}$ & 0.346 & 0.338 & 0.319 & 0.442 \\
\hline & $\begin{array}{l}\text { 1.5 Sensory } \\
\text { Characteristics }\end{array}$ & 0.426 & 0.401 & 0.435 & 0.424 \\
\hline & $\begin{array}{l}\text { 1.6 Ethical Profile } \\
\text { and Image }\end{array}$ & 0.519 & 0.42 & 0.443 & 0.415 \\
\hline \multirow{6}{*}{$\begin{array}{c}\text { Persepsi } \\
\text { Resiko } \\
\text { (X2) }\end{array}$} & 2.1 Fungsi & 0.104 & 0.818 & 0.025 & 0.287 \\
\hline & 2.2 Keuangan & 0.402 & 0.082 & 0.297 & 0.135 \\
\hline & 2.3 Fisik & 0.557 & 0.068 & 0.421 & 0.17 \\
\hline & 2.4 Psikologis & 0.43 & 0.206 & 0.388 & 0.165 \\
\hline & 2.5 Sosial & 0.328 & 0.283 & 0.258 & 0.303 \\
\hline & 2.6 Waktu & 0.482 & 0.233 & 0.411 & 0.193 \\
\hline
\end{tabular}

Table 7:- Correlation Matrix Between Variables

\begin{tabular}{|c|c|c|c|c|c|}
\hline \multirow{3}{*}{ Variabel } & \multirow[b]{3}{*}{ Dimensi } & \multicolumn{3}{|c|}{ Correlations } & \\
\hline & & \multicolumn{4}{|c|}{$\operatorname{Minat} \operatorname{Beli}(\mathbf{Y})$} \\
\hline & & $\begin{array}{c}4.1 \\
\text { Perhatian }\end{array}$ & $\begin{array}{c}4.2 \\
\text { Minat }\end{array}$ & $\begin{array}{c}4.3 \\
\text { Keinginan }\end{array}$ & $\begin{array}{c}4.4 \\
\text { Tindakan }\end{array}$ \\
\hline \multirow{5}{*}{$\begin{array}{c}\text { Persepsi } \\
\text { Harga } \\
\text { (X3) }\end{array}$} & 3.1 Kualitas & 0.203 & 0.228 & 0.222 & 0.686 \\
\hline & $\begin{array}{l}3.2 \text { Biaya yang } \\
\text { dikeluarkan }\end{array}$ & 0.235 & 0.268 & 0.401 & 0.106 \\
\hline & $\begin{array}{l}3.3 \text { Perbedaan } \\
\text { Harga }\end{array}$ & 0.312 & 0.406 & 0.36 & 0.238 \\
\hline & $\begin{array}{l}\text { 3.4 Harga } \\
\text { Referensi }\end{array}$ & 0.311 & 0.257 & 0.443 & 0.309 \\
\hline & $\mathrm{N}$ & 150 & 150 & 150 & 77 \\
\hline
\end{tabular}

*. Correlation is significant at the 0.05 level (2-tailed).

Table 8:- Correlation Matrix Between Variables (Continued)

The interpretation of the correlation matrix is as follows: (1) Show that the largest correlation value between the dimensions in the Quality Perception (X1) variable against the Consumer Purchase Interest (Y) variable is the X1.1 Performance dimension with the Y2 dimension. Interest is 0.684 , and it is included in the category of strong relationship level. This explains that the X1.1 Performance dimension in the Quality Perception variable is indispensable for any increase in Consumer Purchase Interest (Y) especially in the Interest dimension. (2) Show that the greatest correlation value between the dimensions in the Risk Perception (X2) variable to the Consumer Purchase Interest (Y) variable is X2.1 Function with the Y2 dimension. Interest is 0.818 , and it is included in the category of very strong relationship level. This explains 
that the X2 dimension. 1 The function in the Risk Perception variable is indispensable for any increase in Consumer Purchase Interest (Y) especially in the Interest dimension. (3) Show that the largest correlation value between the dimensions in the Price Perception (X3) variable to the Consumer Purchase Interest $(\mathrm{Y})$ variable is the X3.1 Quality dimension with the Y4 dimension. The action is 0.686 , and belongs to the category of strong relationship level. This explains that the dimension X3.1 Quality in the Price Perception variable is indispensable for any increase in Consumer Purchase Interest (Y) especially in the Action dimension. 1 Quality with Y4 dimensions. The action is 0.686 , and belongs to the category of strong relationship level. This explains that the dimension X3.1 Quality in the Price Perception variable is indispensable for any increase in Consumer Purchase Interest (Y) especially in the Action dimension. 1 Quality with Y4 dimensions. The action is 0.686 , and belongs to the category of strong relationship level. This explains that the dimension X3.1 Quality in the Price Perception variable is indispensable for any increase in Consumer Purchase Interest (Y) especially in the Action dimension.

\section{DISCUSSION}

\section{- Quality Perception has a Significant Effect on Consumer Purchase Interest}

The results of the hypothesis show that $\mathrm{H} 1$ is accepted and it is concluded that Quality Perception has a positive and significant effect on Consumer Purchase Interest, meaning that the better the Quality Perception that is owned it will increase Consumer Purchase Interest. This shows that Performance, Range and type of features, Reliability and durability, Maintainability and serviceability Sensory characteristics, DFSK Glory 580 Ethical profile and image must be maintained and improved continuously.

\section{$>$ Risk Perception has a Significant Effect on Consumer Purchase Interest}

The results of the hypothesis show that $\mathrm{H} 2$ is accepted and it is concluded that Risk Perception has a positive and significant effect on Consumer Purchase Interest, meaning that the better the Risk Perception offered to the Consumer, it will increase the Consumer Purchase Interest of Consumers.

\section{> Price Perception has a Significant Effect on Consumer Purchase Interest \\ The results of the hypothesis show that $\mathrm{H} 3$ is accepted and it is concluded that Price Perception has a positive and significant effect on Consumer Purchase Interest, meaning that the better the Price Perception given to the Consumer will increase the Consumer Purchase Interest. This is in line with research, a significant influence between price perception on buying interest. Andra Miranthi (2017) there is a significant influence between the perception of prices on repurchase intention and a significant influence between the perception of prices on buying interest.}

\section{$>$ Managerial Implications}

The results of this study indicate that the perception of quality, risk perception and price perception have a positive and significant relationship to the buying interest of DFSK Glory 580. In an effort to increase buying interest, DFSK Motor CO., LTD. further adding additional features in order to attract consumers to buy the DFSK Glory 580 product, because the role of additional features and product quality must be prioritized. DFSK Motor CO., LTD Indonesia can use a strategy to price DFSK Glory 580 products to be more competitive with car products from other companies, so potential customers can see product quality through prices, so potential customers feel the money they pay for DFSK Glory products 580 accordingly. expected management of DFSK Motor CO.,

\section{CONCLUSIONS AND RECOMMENDATIONS}

\section{A. Conclusion}

Based on the results of research on the effect of quality perception, risk perception, and price perception on DFSK Glory 580 buying interest, the following conclusions can be obtained:

$>$ Quality perception has a significant effect on DFSK Glory 580 buying interest. This is indicated by the value of $\mathrm{t}$ count for perceived quality of 16,140 . So that $\mathrm{t}$ arithmetic> t table (1.97).

$>$ Risk perception significantly influences the buying interest of DFSK Glory 580. This is indicated by the value of $t$ calculated risk perception of 9,487 . So that $t$ count $>\mathrm{t}$ table (1.97).

$>$ Perception of prices significantly influence the buying interest of DFSK Glory 580. This is indicated by the $t$ value of the calculated price perception of 6.011. So that $\mathrm{t}$ count $>\mathrm{t}$ table (1.97).

\section{B. Suggestion}

Based on the findings in this study, several suggestions can be made as follows:

$>$ Theoretically. From the results of hypothesis testing using SPSS shows that R2 $=0.822$, this shows that the variables of perceived quality, perceived risk, and perceived price together significantly influence $82.2 \%$ of DFSK Glory 580 buying interest, while other factors not examined in this study has an effect of $17.8 \%$ on DFSK Glory 580 buying interest. With a good and positive perception from consumers, it is hoped that their perceptions of quality perception, risk perception, and price perception together will increase their buying interest DFSK Glory 580 cars by $82.2 \%$. Suggestions that can be given by researchers for further research are, this study is focused on the influence of perceived quality, perceived risk, and price perception so that it impacts on limited research generalizations. This limitation implies the need for further research to generalize the results obtained in a different and broader context, so that the concepts being tested can be enhanced by their external validity. 
Operationally. Includes the following suggestions (a) Consumer perceptions about the Glory 580 car having a strong endurance of more than 10 years received the highest strongly agreed answer which is 12 respondents to be maintained. While consumers' perceptions about the Glory 580 car having complete features received the lowest disagreeing answer, namely 2 respondents so that the company owner of the DFSK Glory 580 brand would further enhance and add new car features in order to remain competitive with existing competitors. (b) Consumers' perceptions about the impression of the DFSK Glory 580 car will be beneficial for consumers to get the highest totally agreeing answer, which is 6 respondents. While consumers' perceptions are not worried about the mismatch of benefits obtained from the Glory 580 car, the lowest level of agreement is the most agreeable answer, which is 1 respondent. The suggestion is that the Glory 580 car be prioritized towards more suitable target consumers, namely consumers and young families who tend to be more confident about Glory 580 products. (C) Consumer perceptions about the price of Glory 580 cars that fit the pockets of consumers have the highest disagreeing answer that is 5 the respondent must be retained. Whereas consumers' perceptions about the good Glory 580 car warranty have the lowest disagreeing answers, 0 respondents. Excessive guarantees result in negative perceptions and questions from consumers, going forward, the company should review the long car warranty strategy with other more memorable bid strategies. (d) The consumer indicator making the decision to buy Glory 580 has the highest disagreeing answer, 9 respondents must be defended. Whereas the consumer indicator interested in buying a Glory 580 has the lowest most agreeing answer, namely 1 respondent to be further improved by offering several promotions or product offerings with other strategies so that consumers are more interested in buying a Glory 580 car.

\section{REFERENCES}

[1]. Akbar, Muhammad Ridho. (2018). The Effect of Product Quality, Brand Image, and Price Perception on Interest in Buying a Mitsubishi XPander Car in Medan City. Essay. University of Northern Sumatra. Field.

[2]. Andrianto, Hendra Noky. (2013). Effect of Product Quality, Brand Image. Price and Promotion of the Decision to Purchase MPV Type Toyota Kijang Innova in Semarang. Thesis. Diponegoro University. Semarang.

[3]. Budiyanto, I Made. (2016). The Influence of Quality Perception on Purchasing Decisions of Honda Motorcycles in Sidan Village, Kec. Gianyar Kab. Gianyar 2015. Vol 7 No. 2.

[4]. C. Mowen, John. Michael Minor. (2012). Consumer behavior. Erlangga Jakarta.

[5]. Cockrill, Antje and Mark MH Goode. (2010). Perceived Price And Price Decay In the DVD Marke.
The Journal of Product and Brand Management. 19 (5).

[6]. Durianto, Sugiarto. (2011). Strategies to Conquer the Market through Equity Research and Brand Behavior. PT Gramedia Reader. Jakarta.

[7]. Engel, JF, RD Blackwell, and PW Miniard. (2004). Consumer behavior. Volume 1. Sixth Edition. Binarupa Aksara. Jakara

[8]. Fandy Tjiptono (2011). Marketing Services. Bayumedia Publishing. Yogyakarta.

[9]. Freddy Rangkuti. (2012). Business \& Investment Feasibility Study. Gramedia Main Library. Jakarta.

[10]. Ghozali. (2016). Multivariete Analysis Application with the IBM SPSS Program. Diponegoro University Publisher Agency. Semarang.

[11]. Greg Joel, James DD Massie, and Jantje L. Sepang. (2014). The Effect of Motivation, Price Perception, and Product Quality on Consumer Interest in Purchasing Yamaha Mio Matic Motorcycle Brand in the City of Manado. EMBA Journal. Vol.2.No.3. Sam Ratulangi University Manado. Manado.

[12]. Hawkins, DI, and Mothersbaugh, DL (2012). Consumer Behavior: Building Marketing Strategy.11th edition. McGraw-Hill, Irwin.

[13]. Istijanto. (2013). Human Resources Research. Gramedia Main Library. Jakarta.

[14]. Jerry C. Olson and Peter J. Paul. (2000). Consumer behavior and marketing strategies. Nine Edition. Salemba four. Jakarta.

[15]. Kotler, Philip and Armstrong, Gary. (2009). Marketing Principles. Issue 9 Volume 1. Erlangga. Jakarta.

[16]. Kotler, Philip and Armstrong, Gary. (2014). Marketing Principles. Issue 12 Volume 1. Erlangga. Jakarta.

[17]. Kotler, Philip and Keller. (2012). Marketing Management 13. Prentice Hall, Inc. New Jersey.

[18]. Kurniawan, Anggoro Dwi and Sri Rahayu Tri Astuti. (2012). Analysis of Product Influence, Promotion, Price and Place on Purchasing Decisions (Study at Semarang Amarta Store). Diponegoro Journal of Management. Vol.1, No.1, Pg. 282-289.

[19]. Kusumaningtyas, Ghaitsa Damararum. (2017). "The Effect of Country of Origin on Quality Perception and Its Impact on Purchase Interest (Study of Prospective Customers Interested in Buying a Toyota Avanza in Jakarta)". Journal of Business Administration, Vol. 43, No.1.

[20]. Lee, Simon and Lawson-Body, Assion. (2011). Perceived Dynamic Princing. Journal of Industrial Management \& Data System.

[21]. Maharama, Arif Reza. (2016). The Effect of Trust, Ease, and Risk Perception on the Decision to Buy a Gojek Service in Semarang City which is Mediated by Buying Interest as an Intervening Variable. Essay. Sultan Agung Islamic University. Semarang.

[22]. Miranthi, Andra. (2017). Effect of Company Image, Service Quality, and Price Perception on Repurchase Interest through Customer Satisfaction as Intervening Variables. Essay. Diponegoro University. Semarang. 
[23]. Munnukka, J. (2011). Customers Intentions as a reflection of price Perceived. Journal of Product \& Brand Management.

[24]. Nagle, TT and Hogan, J. (2016). The Strategy and Tactics of Pricing, a Guide to Growing more Profitably. Prentice Hall.

[25]. Paul, J. Peter and Jerry C. Olson. (2010). Consumer Behavior: Consumer Behavior and Marketing Strategies. Translate. Erlangga Jakarta.

[26]. Putra, Dimas Ariyanto., Moh Hufron., Afi Rachmat Slamet. (2016). The Effect of Brand Image and Product Quality on Purchasing Decisions of Toyota Agya Cars in Malang City. Unisma FE.

[27]. Schiffman and Kanuk (2013). Consumer behavior. Second Edition. Gramedia Index PT. Jakarta.

[28]. Simamora, Bilson. (2011). Win the Market with Effective and Professional Marketing. PT Gramedia Pustaka Utama. Jakarta.

[29]. Sitinjak, Toni. (2001). Market Conduct Strategy through Equity Research and Brand Behavior. PT. Gramedia Reader. Jakarta.

[30]. Sugiyono (2011). Quantitative R\&D qualitative research methods. Afabeta. Bandung.

[31]. Sugiyono (2012). Educational Research Methods Quantitative, Qualitative, and R\&D Approaches. Alfabeta CV. Bandung.

[32]. Sumarwan, U. (2015). Consumer Behavior, Theory and Its Application in Marketing. Ghalia Indonesia. Jakarta.

[33]. Suprapti, Lilik. (2010). Analysis of the Effect of Brand Awareness, Perceived Value, Organizational Association, and Perceived Quality on Consumer Purchasing Decisions. Essay. Diponegoro University's Faculty of Economics. Semarang.

[34]. Umar, Hussein. (2013). Research Methods for Thesis and Thesis. Rajawali. Jakarta. 